Kapata Arkeologi, 13(1), 73-82

ISSN (cetak): 1858-4101

ISSN (elektronik): 2503-0876

http://kapata-arkeologi.kemdikbud.go.id

\title{
STRATEGI BUDAYA ORANG BUGIS PAGATAN DALAM MENJAGA IDENTITAS KE-BUGIS-AN DALAM MASYARAKAT MULTIKULTUR
}

\section{Cultural Strategy of Pagatan Buginese to Maintain of Bugisnese Identity in Multicultural People}

\author{
Andi Muhammad Akhmar, ${ }^{1}$ Burhanuddin Arafah, ${ }^{2}$ dan Wahyuddin \\ Padirman $^{3}$ \\ Universitas Hasanuddin - Indonesia \\ Fakultas Ilmu Budaya Universitas Hasanuddin, Makassar 90245 \\ 11a_akhmar@yahoo.com
}

Naskah diterima: 02/03/2017; direvisi: 22/03 - 20/06/2017; disetujui: 20/06/2017

Publikasi ejurnal: 25/07/2017

\begin{abstract}
The Pagatan Buginese is a community which living in Pagatan area, Tanah Bambu regency, South Borneo which is culturally identified as Buginese. Even though they are known that their ancestors came from various parts of Sulawesi, the people of this community still identified themselves as separate entity, The Pagatan Buginese. This study use historical, sociolinguistic, and cultural perspective, has revealed that the presences of Buginese in Pagatan occur in several periods. The first period, the Buginese migration to Pagatan in the $18^{\text {th }}$ Century, is the pioneer and founder of Pagatan Kingdom migration. The second period, in the early half of $20^{\text {th }}$ Century, is a large-scale migration caused by Bone War in 1908. The third period, in the second half of $20^{\text {th }}$ Century, is migration when DI/TII Kahar Muzakkar rebellion occurred. Furthermore, in the end of $20^{\text {th }}$ Century, Buginese fisherman communities, who are initially only fishing in Pagatan, gradually bring their family and settle there which is known as pappagatang. The Buginese domination in socio-cultural, economy, and political sector is generated by their ability to adapt to other communities, especially Banjar as the native of Borneo. The Buginese have a number of excellences in agriculture, fishery, maritime, and trading sector, as well as the eminent ethos that rooted from cultural value sirri na pesse (dignity and compassion) and other living philosophy of Buginese.
\end{abstract}

Keywords: Migration, the Pagatan Buginese, identity, ritual

\begin{abstract}
Abstrak
Orang Bugis Pagatan adalah sebuah komunitas yang tinggal di kawasan Pagatan, Kabupaten Tanah Bumbu, Provinsi Kalimantan Selatan, yang secara kultural diidentifikasi sebagai orang Bugis. Meskipun Orang Bugis Pagatan mengakui jika leluhurnya berasal dari sejumlah daerah Sulawesi Selatan, namun tetap mengidentifikasi diri sebagai sebuah entitas tersendiri, yaitu orang Bugis Pagatan. Penelitian yang menggunakan perspektif sejarah, sosiolinguistik, dan kajian budaya ini mengungkapkan bahwa keberadaan orang-orang Bugis di Pagatan berlangsung dalam beberapa periode. Periode pertama migrasi orang Bugis ke Pagatan pada abad ke-18, adalah kalangan perintis sekaligus pendiri kerajaan Pagatan. Periode kedua migrasi orang Bugis ke Pagatan berlangsung pada paruh awal abad abad ke-20, merupakan migrasi dalam skala besar yang diakibatkan oleh pecahnya perang Bone tahun 1908. Periode ketiga migrasi orang Bugis ke Pagatan pada paruh kedua abad ke-20, yaitu saat berlangsungnya peristiwa pemberontakan DI/TII Kahar Muzakkar. Selain itu, pada akhir abad ke-20, terdapat pula kelompok-kelompok nelayan Bugis yang pada awalnya hanya mencari ikan di Pagatan, berangsur-angsur membawa keluarga mereka menetap di sana, yang dikenal dengan istilah pappagatang. Dominasi orang Bugis pada sektor sosial budaya, ekonomi, dan politik disebabkan oleh kemampuan mereka beradaptasi dengan komunitas lain, khususnya orang-orang Banjar sebagai penduduk asli Kalimantan. Orang Bugis memiliki sejumlah keunggulan dalam bidang pertanian, perikanan, kelautan, dan perdagangan, serta memiliki etos kerja yang tinggi yang bersumber dari nilai-nilai budaya siri na pesse (harga diri dan rasa iba) serta filosofi hidup orang Bugis lainnya.
\end{abstract}

Kata kunci: Migrasi, Bugis Pagatan, identitas, ritual 


\section{PENDAHULUAN}

Komunitas orang Bugis Pagatan di Kecamatan Kusan Hilir, Kabupaten Tanah Bumbu, Provinsi Kalimantan Selatan tergolong unik karena mereka memiliki ikatan sosial yang kuat serta masih memelihara tradisi dan budaya mereka. Pertama, secara terjadwal mereka menyelenggarakan upacara tahunan yang dikenal dengan nama mappanre tasiq (sesajian untuk laut), sesungguhnya tradisi ini sudah jarang dipraktikkan oleh orang Bugis di Sulawesi Selatan. Kedua, komunitas Bugis di Kabupaten Tanah Bumbu sangat berperan dalam bidang pembangunan ekonomi, khususnya di sektor perdagangan. Dalam bidang politik, komunitas ini juga sangat menonjol, terbukti selama 3 (tiga) periode terakhir, keturunan Bugis Pagatan menjadi Bupati di daerah ini. Ketiga, komunitas ini juga dapat hidup berdampingan dengan damai dengan orang Banjar dan orang Dayak sebagai penduduk asli, serta dengan masyarakat pendatang lainnya yang berasal dari Pulau Jawa, Madura, Sumatera, dan lain-lain. Mereka bukan lagi orang Bugis seperti orang Bugis yang hidup dan lahir di Sulawesi Selatan, justru mereka menolak disamakan dengan itu. Oleh karena itu, keturunan Bugis ini membuat penyebutan khusus untuk membedakan diri dengan nama "Bugis Pagatan." Meski demikian, mereka juga sangat menghargai sejarah asal usul dan tradisi nenek moyang mereka yang berasal dari Sulawesi Selatan. Mereka melestarikan dan bahkan telah mendirikan lembaga adat yang disebut 'Ade Ogi-Pagatan.' Fakta-fakta ini menarik dikaji dari segi bahasa dan kebudayaan agar dapat diketahui bagaimana komunitas Bugis Pagatan ini mampu merawat identitas dan tradisi mereka di tengah-tengah pluralisme budaya dan arus modernisasi yang demikian kuat membawa perubahan pada kehidupan sosial masyarakat.

Meskipun demikian, keberadaan budaya dan tradisi orang Bugis Pagatan ini juga menghadapi tantangan era modern yang secara umum dapat dilihat dari dua bentuk. Bentuk tantangan pertama datang dari negara, sementara bentuk tantangan yang kedua datang dari proses globalisasi kebudayaan lokal yang terancam oleh kecenderungan negara dalam membangun identitas kebudayaan berciri nasional. Meskipun sesungguhnya dalam konsep kebudayaan Indonesia, kebudayaan nasional tidak lain diasalkan pada kebudayaan lokal/daerah atau disebut kebudayaan nasional adalah puncak-puncak dan kebudayaan daerah namun pengalaman berkebudayaan dalam masa Orde Baru secara nyata meminggirkan kebudayaan-kebudayaan lokal tertentu baik itu disengaja maupun tidak disengaja. Pembangunan identitas nasional bisa secara perlahan mematikan identitas lokal. Hal tersebut dapat kita jumpai, misalnya pada pemakaian bahasa daerah sebagai salah satu bagian kebudayaan yang penting ketika tingkat penggunaan bahasa daerah semakin jarang. Jika hal tersebut berlangsung secara berkesinambungan, maka pada akhirnya bahasa daerah tersebut akan dilupakan oleh penuturnya. Hal yang lebih mengundang perhatian jika yang dibicarakan adalah kebudayaan dalam bentuknya yang lain seperti tradisi, upacara ritual kelompok masyarakat lokal, semakin pudar seiring dengan politik pendidikan yang berciri rasional yang dimassifkan oleh institusi pendidikan negara.

Dalam menghadapi hal seperti itu, seseorang memang tidak bersikap romantisa historis, yakni bersikap seolah-olah mampu mempertahankan suatu kebudayaan seperti apa adanya kebudayaan itu di masa lain. Namun, yang menjadi pokok persoalannya adalah bagaimana strategi yang dapat dilakukan agar niai-nilai tertentu yang berharga dari satu kebudayaan lokal (local wisdom) bisa dipertahankan, dipelajari, dan diaktualkan dalam kehidupan modern. Bentuk kebudayaan barangkali sulit untuk dipertahankan, tetapi isi atau nilai kebudayaan itu penting dijaga. Paling tidak dua alasan mengapa nilai kebijaksanaan lokal perlu dijaga, yaitu pertama adalah alasan identitas dan yang kedua adalah alasan manusia yang membutuhkan orientasi hidup.

Dari sisi sejarah, kelahiran bangsa Indonesia atau pengakuan keindonesiaan tidak mensyaratkan peleburan total kebudayaan lokal kedalam sebuah nilai baru yang berciri keindonesiaan. Justru Indonesia lahir dan bertumbuh-kembang di atas aneka ragam perbedaan termasuk perbedaan kebudayaan yang berciri kedaerahan. Semboyan Bhineka Tunggal Ika diambil sebagai pengikat oleh para pendiri bangsa yang mensyaratkan di dalamnya perbedaan di antara suku bangsa yang ada. Oleh karena itu, tantangannya adalah mengelola perbedaan-perbedaan yang ada agar tidak 
menjadi kontraproduktif dalam pembangunan tetapi menjadi sumberdaya yang kuat dalam mendukung pembangunan bangsa. Pada sisi lain, semangat menjaga kebudayaan lokal tidak boleh juga terjatuh pada sikap fundamentalis tanpa rasionalitas. Jika hal itu terjadi maka dipastikan Indonesia akan menjadi lahan subur konflik lintas budaya, sebagaimana kejadian konflik yang berlatar agama dan budaya pasca reformasi, seperti konflik Ambon, Poso, dan Sampit.

Uraian tersebut di atas memperlihatkan bahwa kebudayaan lokal di hadapan negara memiliki relasi timbal-balik. Negara tidak boleh mematikan atau mensub-ordinasi kebudayaan lokal atas nama kebudayaan nasional. Jika hal itu terjadi, maka resikonya bangsa Indonesia akan kehilangan nilai-nilai lokal yang berharga yang pada akhirnya kita akan kehilangan identitas diri dan kehilangan sebuah orientasi hidup, atau dengan kata lain, bangsa tersebut akan kehilangan pijakan arah pengembangan diri dan kebudayaannya. Kebudayaan lokal di sisi lain tidak bisa menjadi sangat fundamental sebab sudah menjadi kenyataan bahwa bangsa Indonesia memiliki akar pada kebudayaan lokal tertentu, hidup dalam negara yang berciri multietnik, multiagama dan sejumlah multi perbedaan lainnya. Menguatnya sentimen kelokalan baik itu suku, agama dan kelompok primordial lainnya akan membuka ruang konflik horizontal sebagaimana yang pernah terjadi akan menjadi ancaman di masa yang akan datang.

Negara berada di bawah sebuah entitas yang lebih besar yang bersifat supra bangsa, yakni pasar. Kebudayaan lokal selain memiliki tantangan dan negara, tantangan lain yang tak kalah hebatnya datang dari pasar bebas dalam era yang disebut globalisasi. Luruhnya batasbatas geografi dan semakin intensnya interaksi lintas budaya melahirkan terbentuknya kelompok-kelompok sosial baru. Komunitas yang lahir karena inovasi teknologi dapat kita saksikan semakin menjamur. Komunitas dalam facebook, twitter, dan komunitas sejenisnya mengancam generasi muda dari kelompok masyarakat yang lebih dulu eksis dengan segala tata nilai yang telah dianutnya. Nilai-nilai lokal menghadapi tantangan, apakah generasi muda yang berpendidikan dan melek teknologi masih mengadopsi nilai-nilai dari kebudayaan lokal mereka ataukah justru nilai itu telah hilang sama sekali dan telah berganti dengan nilai-nilai baru yang lebih dilihat sejalan dengan logika masyarakat pasar bebas hari ini.

Pada bagian latar belakang telah diuraikan bahwa orang Bugis Pagatan dapat hidup berdampingan dengan orang Banjar dan orang Dayak sebagai penduduk asli di Kabupaten Tanah Bumbu, serta hidup berdampingan dengan masyarakat pendatang lainnya, seperti orang Jawa, Madura, Sunda, dan lain-lain. Orang Bugis bahkan dapat dikatakan cukup menonjol dalam kehidupan budaya, ekonomi, dan politik. Berdasarkan hal tersebut, dapat dirumuskan pertanyaan dalam penelitian ini sebagai berikut: Pertama, bagaimana kehidupan sosial, budaya dan politik masyarakat Bugis Pagatan? Kedua, bagaimana strategi kebudayaan komunitas Bugis Pagatan kaitannya dengan mempertahankan identitas Kebugisan mereka?

\section{METODE}

Dalam mengumpulkan data, peneliti melakukan wawancara mendalam (in depth interview) terhadap masyarakat Bugis Pagatan guna menggali informasi tentang ingatan kolektif tentang asal-usul mereka, cerita-cerita lisan, tentang bagaimana mereka menggambarkan dirinya sendiri. Metode ini juga digunakan untuk mendapatkan informasi bagaimana masyarakat lain (Banjar, Dayak, Jawa, dan Bali) memandang keberadaan masyarakat Bugis Pagatan ini. Penelitian ini juga menggunakan metode observasi untuk mengumpulkan data tentang penggunaan bahasa mereka dalam keseharian, bagaimana model pewarisan bahasa daerah terhadap generasi muda mereka. Metode observasi juga digunakan untuk merekam setiap peristiwa adat, ritual yang mereka selenggarakan seperti perkawinan, mappanre tasiq dan lain-lain. Metode kepustakaan juga digunakan untuk mendapatkan informasi sejarah tentang masyarakat Bugis Pagatan dan interaksi mereka dengan kelompok masyarakat lainnya.

Metode analisis data yang digunakan adalah deskriptif analisis. Metode ini digunakan untuk menggambarkan dan menganalisis bukan hanya kondisi periode kini, melainkan juga perkembangan masyarakat Bugis Pagatan berdasarkan kurun waktu serta perubahanperubahan yang terjadi di dalamnya, serta menggambarkan mengapa hal tersebut terjadi. 
Adapun lokasi pengumpulan data adalah di Kecamatan Kusan Hilir dan Batu Licin, Kabupaten Tanah Bumbu, Provinsi Kalimantan Selatan

\section{HASIL DAN PEMBAHASAN \\ Fase Awal Kedatangan Migran Bugis}

Dalam catatan seorang sarjana

Kebangsaan Belanda, Nagtegaal, Pagatan sebagai sebuah pemukiman telah berdiri pada sekitar tahun 1750. Hal tersebut sejalan dengan keterangan dalam lontara yang ditulis pada tanggal 21 Agustus 1868 oleh Kapiten La Mattone (seorang petinggi kerajaan Pagatan) yang mengatakan bahwa saudagar-bangsawan Bugis dari Wajo Sulawesi Selatan tiba di Pagatan pada pertengahan abad ke XVIII yang dipimpin oleh seorang yang bernama Puanna Dekke. Pada awal kedatangan saudagar tersebut, ia sebenarnya telah lebih dahulu singgah di muara Sungai Samarinda dan muara Sungai Pasir. Namun karena kurang cocok dengan wilayah tersebut, Puanna Dekke melanjutkan perjalanan. Namun, dalam perjalanannya datang badai yang memaksanya untuk merapat ke muara Sungai Kukusan yang sekarang ini dikenal dengan sebutan Sungai Kusan. Pada saat itu, wilayah Sungai Kusan belum dihuni oleh manusia kecuali beberapa orang Banjar yang datang ke wilayah tersebut untuk membersihkan rotan. Dari orang-orang Banjar tersebut, para saudagar-bangsawan Bugis mengetahui nama wilayah Pamagatan yang berarti 'tempat pembersihan dan pemotongan rotan.' Daerah Pamagatan kala itu merupakan bagian dari daerah kekuasaan Kerajaan Banjar.

Dalam riwayat dan sejarah Kabupaten Tanah Bumbu (2013) tertulis bahwa terbentuknya Pagatan diawali oleh kehadiran suku Bugis dari Wajo yang kemudian disusul oleh kehadiran orang-orang Bugis dari wilayah lainnya secara bertahap. Mengutip seorang sarjana Belanda, Eisen Berger (1750) disebutkan bahwa pada awal-awal tahun 1729, Puanna Dekke, seorang saudagar Wajo memimpin pembukaan lahan, mengembangkan pertanian dan penangkapan hasil laut. Merasa cocok dengan wilayah tersebut, para saudagar Bugis ini menghadap Panembahan Batu atau Sultan Kuning sebagai raja Kerajaan Banjar saat itu. Maksud mereka ialah hendak memohon izin untuk mendiami wilayah
Pamagatan secara permanen. Sang Sultan menyetujui keinginan Puanna Dekke. Ia hanya mengatakan bahwa kalau Punna Dekke sanggup mengeluarkan biaya untuk membuka lahan hutan belantara sebagai pemukiman silahkan saja namun ia juga harus mengetahui bahwa wilayah tersebut merupakan tempat para perompak atau bajak laut sering singgah. Mendengar pernyataan Sultan, Puanna Dekke bertanya balik bahwa jika sekiranya ia telah mengeluarkan biaya, bagaimana hal ihwal wilayah tersebut. Sang Sultan pun menjawab bahwa jika memang sekiranya demikian, maka wilayah yang telah dibuka jadi lahan perkampungan itu dapat diwariskan kepada anak cucu mereka kelak tanpa ada yang berhak mengganggu.

Setelah mendapat izin dari Sultan Banjar, Puanna Dekke dibantu saudaranya yang datang dari Pontianak, Pua Janggo dan kakeknya Pua Ado La Pagala beserta rombongan lainnya mulai menebang pohon-pohon dalam hutan belantara untuk dijadikan pemukiman. Pemukiman tersebut lalu dinamai Pagatang yang diambil dari kosa kata bahasa Banjar (Memagat: mencari rotan). Dari hasil penelusuran diketahui bahwa sebenarnya ketika perkampungan Pagatan dibuka, daerah itu sebenarnya telah dihuni oleh beberapa penduduk asli yakni Suku Banjar. Bahkan seorang ulama Islam yakni Syekh Abu Thalhah bin Syekh Mufti H.M As'ad seorang cucu dari Syekh Muhammad Arsyad Al Banjari telah bermukim. Usai perkampungan Pagatan dirasakan telah layak huni, berundinglah Puanna Dekke bersama saudaranya untuk menjemput cucu mereka di Wajo tepatnya di daerah Kampiri yang bernama La Pangewa. La Pangewa ini merupakan turunan anak raja yang sebenarnya dipersiapkan menjadi raja di kerajaan Wajo, namun kemungkinan besar karena situasi perang antara kerajan-kerajaan di Sulawesi saat itu menyebabkan Puanna Dekke bersama saudaranya memutuskan untuk menjemput La Pangewa untuk dipersiapkan menjadi raja di Pagatan. Selain itu, para migran Bugis Wajo ini juga membutuhkan sebuah ikon pemersatu di antara mereka.

Ketika La Pangewa dijemput, usianya saat itu baru beranjak remaja. Menurut cerita, ia bahkan dikhitan setelah berada di Pagatan. Dalam usianya yang masih remaja inilah $\mathrm{La}$ Pangewa dinobatkan menjadi raja Pagatan I. 
Menurut penuturan A. Satria Jaya, seorang keturunan XII Raja Pagatan pertama La Pangewa, ketika generasi pertama migrasi Bugis datang ke Pagatan, mereka menetap di sekitar daerah pesisir pantai dan pinggiran aliran sungai. Beberapa di antara mereka ada juga yang memilih untuk tinggal di daerah pegunungan. Karena itu, sejak awal kedatangan para migran tersebut telah berprofesi sebagai petani dan nelayan.

Pada suatu saat ketika intensitas gangguan dari para bajak laut meningkat terhadap para saudagar-saudagar dari beragai daerah yang hendak ke Pagatan dan Banjarmasin untuk berniaga, Puanna Dekke mengutus cucunya, La pangewa untuk melaporkan hal tersebut ke Panembahan, Sultan Banjar. La Pangewa, oleh Sultan lalu diminta memimpin pasukan untuk menumpas para bajak laut tersebut. Atas keberhasilan misinya menumpas para penganggu pelayaran itu, La Pangewa dinobatkan secara resmi oleh Sultan Banjar sebagai sebagai Raja Pagatan I dengan gelar Kapitan Laut Pulo. Atas kesuksesan tersebut, Panembahan kembali menegaskan ulang komitmennya terhadap wilayah kerajaan Pagatan dengan mengatakan bahwa "Sekarang ini kutegaskan lagi kepada anda Kapiten, adapun Pagatan yang sudah kuserahkan pada kakek anda dan pada waktu sekarang ini anda lagi yang memiliki Pagatan. Maka milikilah untuk diwariskan kepada anak cucu anda, tidak ada yang mengganggu gugat anak cucu anda tinggal di Tanah Pagatan" (www. kskkusanhilir.com). Peristiwa ini, kemudian diyakini oleh masyarakat Pagatan sebagai cikal bakal berdirinya Kerajaan Pagatan yang jejaknya hari ini masih dapat ditemui di Kabupaten Tanah Bumbu, kecamatan Kusan Hilir di Propinsi Kalimantan Selatan.

Perpindahan besar-besaran orang Bugis dari kampungnya di di Sulawesi Selatan ke beberapa tempat, antara lain di Pulau Kalimantan dan Pulau Sumatera dimulai pada paruh kedua abad ke-17 (Andaya, 2010: 119138). Dalam sejarah Sulawesi-Selatan dapat dibaca bahwa pada tahun-tahun tersebut terjadi perang besar-besaran yang melibatkan hampir semua kerajaan-kerajaan yang ada diperparah dengan kehadiran pasukan kompeni Belanda dengan politik pecah belahnya. Pendapat serupa juga disampaikan oleh Mattulada (1998: 145) bahwa terjadi perpindahan peduduk pada abad ke-17 yang sangat massif. Tujuannya baik ke pulau-pulau besar maupun pulau-pulau kecil di Pulau jawa, Sumatera dan semenanjug Malaka. Perpindahan penduduk itu terjadi kebanyakan terdorong oleh keadaan dalam negeri yang kurang aman. Kaum bangsawan banyak kehilangan sumber-sumber penghasilan dan mata pencaharian. Zaman itu suasana kependudukan amat pelik untuk diatur. Tampaknya perang telah sungguh-sungguh menggerogoti kehidupan masyarakat. Banyak sumber-sumber kehidupan yang hancur, sawahsawah tidak terurus karena rakyat ikut perang, bayak lumbung yang terbakar saat pendaratan Speelman, si Kapten Belanda untuk mengkonfirmasi sejarah Pagatan yang menyebutkan bahwa orang Bugis Wajo pada abad ke-18 yang pertama kali mendirikan Kerajaan Pagatan, ada baiknya kita melihat sejarah masyarakat Sulawesi-Selatan khususnya Tana Wajo pada abad tersebut. Mattulada (1998: 289-230) mengemukakan bahwa Tana Wajo, atau orang Wajo yang bersekutu dengan Butta Gowa dalam 'perang makassar' sampai pada akhir abad ke-17, sangat tertekan oleh Tana Bone. Beberapa wilayah, negeri bawahan Tana Wajo dicaplok dan diduduki oleh orang Bone, dan menekan kebebasan orang Wajo dalam berbagai bidang kehidupan. Tekanantekanan itu menyebabkan orang Wajo banyak meninggalkan negerinya, ke Makassar atau tempat/negeri lain, menjadi pengusaha, pedagang yang cekatan dan berhasil menjadi saudagar yang kaya.

Pada zaman kekuasaan Arung Palakka La Tenritatta, dan La Patau sebagai Arumpone, orang Wajo menerima pertuanan mereka. Keberatan-keberatan atau keluhan-keluhan orang Wajo atas kekuasaan itu tidak dapat dilayani oleh pihak kompeni Belanda walaupun diketahui bahwa Tana Wajo adalah negeri Vasal Kompeni. Tetapi pengaruh dan kedudukan Arung Palakka La Tenritatta, sehingga orang Wajo menerima kenyataan itu. Pihak Kompeni Belanda menyadari hal itu, namun tidak dapat berbuat banyak bagi orang Wajo. Demikianpun ketika La Patau menjadi Arumpone, pengaruh itu masih dapat berlanjut, walaupun tidak sekuat pendahulunya.

Seorang tokoh Tana Wajo yang meninggalkan Tana Wajo ketika kekuasaan dan pengaruh Arung Palakka La Tenritatta masih sangat kuat adalah La Maddukelleng Arung 
Sengkang. Ia baru kembali ke Tana Wajo untuk memulihkan kembali harkat dan martabatnya sebagai orang merdeka pada permulaan abad ke-18. La Madukelleng Arung Sengkang kemudian menjadi Arung Matua Wajo pada periode 1738-1754. Ia berhasil mengangkat kembali martabat Tana Wajo dengan melaksanakan asas Maradeka to-Wajo, ade'mi napopuang (Merdeka orang Wajo, hanya hukumlah yang dipertuannya). Ia dilantik menjadi Arung Matoa Wajo pada tanggal 6 November 1736. Ia juga dikenal dengan gelar Sultan Pasir, karena pernah bermukim di daerah (sekarang Kabupaten Paser, Provinsi Kalimantan Timur) dan memperistri puteri Sultan Pasir. Setahun sebelum ia menjadi Arung Matoa Wajo, dalam bulan Desember 1735, bersama kawan-kawannya antara lain Arungta La Dalle Puanna Pabbola dan Kapitan Lau' bernama To-Assa, menyerang Mandar dengan menggunakan sebuah armada perahu layar bersenjata.

Melihat hasil penelitian Mattulada tersebut memang terlihat bahwa antara Wajo dan daerah Kalimantan pada abad ke-17 telah terjalin hubungan, paling tidak orang Wajo telah melakukan perjalanan ke daerah tersebut. Bahkan Arung Matoa Wajo telah menikahi anak dari Sultan Pasir. Dalam catatan sejarah (terdapat beberapa versi), raja pertama Pagatan, yakni La Pangewa yang digelari Kapiten laut pulo (Pulau laut) memerintah pada pertengahan abad ke-18, namun demikian terdapat perbedaan waktu, ada yang mengatakan tahun 1755, ada pula yang mengatakan mulai tahun 1761. Dari keterangan tersebut kemungkinan besar yang membantu Arung Matoa Wajo menyerang Mandar adalah La Pangewa. Hal tersebut dilihat dari kesamaan gelar yang dirujuk yakni Kapiten Lau.' Gelar tersebut adalah gelar yang diberikan oleh Sultan Banjar kepada La Pangewa sebagai Raja Pagatan. Namun mengapa Mattulada mencatat bahwa nama dari Kapiten Lau' adalah To Assa bukan La Pangewa? Hal tersebut tampaknya bersumber dari kebiasaan orang Bugis untuk menyingkatkan penyebutan nama seseorang. Sebenarnya nama lengkap dari La Pangewa adalah Hasan La Pangewa. 'To Assa' merupakan penyingkatan dari nama 'Hasan' dengan mengalami proses morfemis tertentu sehingga menjadi 'Assa.'
Kerajaan Pagatan yang dahulunya diserahkan oleh Sultan Banjar meliputi sebuah wilayah yang cukup luas. Namun setelah sistem pemerintahan Kerajaan Pagatan dihapuskan oleh Belanda pada tanggal 1 Juli 1912 dengan staatblads 1912 no 312, maka wilayahnya semakin mengecil. Dewasa ini, Pagatan bahkan tidak lebih dari sebuah wilayah setingkat desa yang menjadi ibukota kecamatan Kusan Hilir, Kabupaten Kota Baru, Provinsi Kalimantan Selatan. Meskipun wilayahnya semakin kecil, nama Pagatan masih melekat sebagai simbolisme historis masyarakat rantau. Orangorang Bugis, bahkan termasuk yang tinggal di luar Pagatan mengidentifikasi dirinya sebagai Bugis Pagatan.

\section{Dinamika Kehidupan Masyarakat Bugis Pagatan}

Dalam struktur administrasi pemerintahan sekarang, Pagatan merupakan nama sebuah desa di Kecamatan Kusan Hilir, Kabupaten Tanah Bumbu, Propinsi Kalimantan Selatan. Meskipun dalam tulisan ini, sering disebutkan istilah Bugis Pagatan, namun hal tersebut tidaklah merujuk pada orang-orang Bugis yang hanya tinggal di Dsa Pagatan sebab istilah tersebut nampaknya merujuk pada komunitas orang-orang Bugis yang dahulu hidup dalam wilayah Kerajaan Pagatan yang wilayahnya melebihi dari apa yang menjadi wilayah setingkat desa yang disebut Pagatan hari ini.

Wilayah-wilayah yang dihuni oleh orang Bugis Pagatan selain yang menetap di desa Pagatan, juga mencakup mereka-mereka yang hidup di desa-desa yang terletak di pinggir pantai. Desa-desa tersebut adalah Desa Wiritasi, Gusunge, Jukueja dan Pejala. Hal ini menunjukkan bahwa memang istilah 'Pagatan' di belakang istilah 'Bugis' tidak mengacu pada wilayah Desa Pagatan yang ada dewasa ini tetapi mengacu khususnya pada wilayahwilayah dimana Kerajaan Pagatan dulu eksis, yakni wilayah-wilayah yang berada di pinggir pantai. Mereka-mereka yang menempati wilayah-wilayah tersebutlah yang mengaku nenek moyang mereka telah berada di sana sejak abad ke-18 dan 19. Mereka inilah yang mengaku sebagai Bugis Pagatan dan membedakan diri dengan orang-orang Bugis yang merantau ke wilayah sekitar Pagatan, 
seperti di Kota Baru, Batu Licin maupun daerah lainnya yang berada di sekitarnya.

Jika diperhatikan dari segi morfologi wilayah, desa-desa yang dihuni oleh Bugis Pagatan ini adalah daerah pinggir pantai. Empat desa yakni Wiring Tasi, Gusunge, Jukueja dan Pejala merupakan wilayah yang langsung berhadapan dengan laut, sementara itu Pagatan sendiri letaknya tidak berbatasan langsung dengan laut. Mengingat wilayahnya berbatasan dengan laut, aktifitas masyarakat Bugis Pagatan yang tinggal di empat desa tersebut, mayoritas hidup sebagai nelayan. Bau ikan yang dikeringkan begitu menyengat ketika memasuki wilayah-wilayah tersebut. Sementara itu, di Pagatan sendiri yang sebenarnya merupakan sebuah desa, ibukota kecamatan Kusan Hilir menjadi wilayah ekonomi yang lebih kompleks. Pasar sentral kecamatan terletak di Pagatan ini, demikian pula kantor-kantor pemerintah tingkat kecamatan, masjid raya Kusan Hilir terletak di Pagatan. Karena itulah masyarakat Pagatan terlihat sudah sangat multikultural, sejumlah komunitas hidup berdampingan, di antaranya Bugis, Banjar, Jawa, Cina, Madura dan Dayak. Hal ini agak berbeda dengan masyarakat di empat desa yang disebutkan sebelumnya, sebagian besar merupakan masyarakat Bugis Pagatan.

Keempat desa di Kecamatan Kusan Hilir tersebut adalah wilayah-wilayah tua yang menjadi pemukiman bagi perantau-perantau Bugis terdahulu. Meskipun hari ini banyak juga diantara anak-anak mereka yang sudah menikah lintas etnis dan telah bercucu cicit di daerah itu, namun suasana budaya Bugis masih sangat tampak terutama karena bahasa Bugis menjadi bahasa sehari-hari. Bahkan dalam satu kunjungan ke rumah salah seorang warga, terdengar mereka mendegarkan lagu-lagu Bugis. Lain halnya di Pagatan sendiri, meskipun kita masih bisa mendengarkan penggunaan Bahasa Bugis tetapi secara umum orang-orang menggunakan bahasa Indonesia, meskipun sebenarnya mereka juga adalah Bugis Pagatan. Hal tersebut karena interaksi masyarakatnya memang sudah sangat majemuk. Menurut pengakuan warga (statistik daerah tidak mencantumkan etnis), dewasa ini penduduk Pagatan selain etnik Bugis dan Banjar, etnis Jawa semakin banyak berdatangan dari hari ke hari.
Rumah-rumah masyarakat Bugis Pagatan yang tinggal di pinggir pantai berjejer dengan agak rapat. Bentuk rumah-rumah mereka bervariasi, ada yang menggunakan kayu sebagai bahan dasarnya (rumah kayu) namun ada juga yang menggunakan rumah-rumah yang bahan utamanya dari batu-bata (rumah batu). Hal ini terkait dengan tingkat ekonomi masing-masing keluarga. Hal yang agak mencolok adalah jarang dijumpai rumah yang menggunakan tiang-tiang kayu yang tinggi sebagai penopang seperti yang dijumpai dalam konstruksi rumahrumah orang Bugis di Sulawesi yang banyak menggunakan tiang-tiang tinggi (alliri'). Tiang penyangga rumah dibuat dengan bentuk yang sangat pendek, sehingga jarak antara lantai rumah dari tanah hanya berjarak sekitar $60 \mathrm{~cm}$.

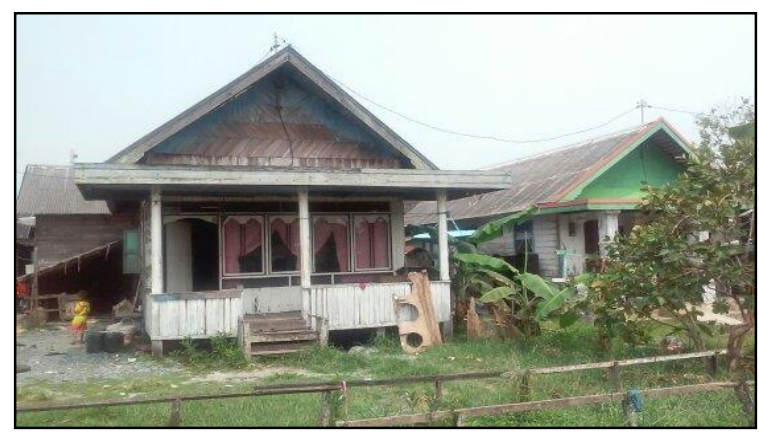

Gambar 1. Gambar Rumah orang Bugis Pagatan (Sumber: Dokumentasi Penulis, 2016)

Seperti telah dikemukakan, mata pencaharian pokok masyarakat Pagatan adalah nelayan, entah itu sebagai nelayan yang memiliki perahu penangkap ikan sendiri ataupun nelayan yang bekerja pada seorang juragan. Menjadi sebuah pemandangan keseharian, baik perahu yang kecil yang digunakan oleh hanya satu atau dua orang nelayan maupun perahu yang cukup besar yang menampung puluhan nelayan tampak hilir mudik dan terparkir di sepanjang pantai dan juga di sungai Pagatan. Salah satu yang menjadi ciri khas daerah ini juga adalah sungainya yang masih cukup dalam sehingga dapat dilayari oleh perahu nelayan yang bentuknya lumayan besar.

Selain sebagai nelayan, sebagian diantara mereka bekerja sebagai penjual ikan atau pedagang barang lain di Pasar Pagatan. Boleh dikatakan bahwa dunia perdagangan di Pagatan diisi juga oleh orang Bugis Pagatan, bahkan dari pengamatan peneliti orang Bugis menjadi pelaku perdagangan dominan di Pagatan. 
Sekitar $90 \%$, penjual ikan adalah orang Bugis, kalaupun ada orang lain non-Bugis, disebabkan karena telah menjadi kerabat orang Bugis melalui perkawinan.

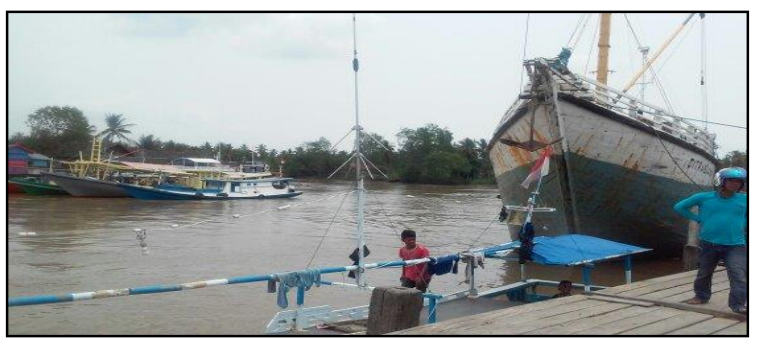

Gambar 2. Gambar perahu-perahu nelayan di pinggir sungai Pagatan

(Sumber: Dokumentasi Penulis, 2016)

Ammarel (2002: 51-67) menyebutkan sebagai migran, orang Bugis dikenal sebagai pekerja keras dan sukses dalam membuka relung ekonomi yang belum tereksploitasi sebelumnya dengan cara membuka lahan pertanian, mengembangkan ternak ikan dan mendirikan usaha kecil. Bidang yang terakhir itulah yang juga ditemukan pada masyarakat Bugis Pagatan. Karena wilayah Pagatan sebagian besarnya berada di pinggir laut, maka hampir tidak ditemukan lahan pertanian. Sawah dan kebun berada di luar Pagatan. Meskipun sebenarnya banyak pula orang-orang Bugis yang mengerjakan sektor pertanian, namun ada perbedaan dengan Bugis Pagatan. Seperti telah dikemukakan bahwa yang disebut Bugis Pagatan adalah orang-orang yang tinggal di Pagatan, nenek moyang mereka telah berada di daerah tersebut sejak abad ke-17 dan 18. Berbeda dengan orang Bugis yang berada di luar kota Pagatan, khususnya wilayah sepanjang arah Batu Licin, mereka bisa dikategorisasi sebagai orang Bugis yang nenek moyangnya merantau pada pertengahan abad ke-20, atau pun yang merantau beberapa tahun terakhir ke daerah tersebut.

\section{Upaya Orang Bugis Pagatan Merawat Identitasnya}

Identitas orang Bugis Pagatan ditandai dengan beberapa hal, diantaranya penggunaan bahasa Bugis, penamaan orang, penamaan tempat, pakaian tradisional, pelaksanaan ritual, masakan atau makanan, dan pekerjaan. Tujuh hal ini dibicarakan dalam konteks identitas etnik adalah sebagai berikut.

\section{Pemakaian Bahasa Bugis}

Sebagaimana dibicarakan pada pembahasan terdahulu bahwa orang Bugis Pagatan menggunakan bahasa Bugis dalam berkomunikasi di kalangan mereka. Sebagaimana layaknya orang Bugis di Sulawesi Selatan, mereka menggunakan bahasa Bugis dengan lancar. Akan tetapi, dialek yang mencerminkan daerah (Bone, Sinjai, Wajo, dan lain-lain) tidak menonjol lagi, bahkan cenderung membentuk dialek baru, yaitu Bugis Pagatan. Selain di rumah, bahasa Bugis terlihat banyak digunakan di masjid dan terutama di pasar Pagatan. Dalam transaksi jual beli di pasar, terutama di lokasi jual ikan Pasar Pagatan, pada umumnya menggunakan bahasa Bugis. Tidak sedikit, bahkan di antara orang Banjar, Dayak, Jawa, Madura, dan bahkan orang Cina ikut menggunakan bahasa Bugis dalam transaksi jual beli tersebut. Penggunaan bahasa Bugis di lingkungan keluarga maupun di ranah publik merupakan suatu upaya orang Bugis Pagatan mempertahankan identitas kebugisan mereka di tengah masyarakat yang plural.

Hal yang menjadi kekhawatiran beberapa orang tokoh masyarakat Bugis Pagatan adalah keberadaan kalangan muda, terutama yang lahir setelah era reformasi. Kalangan muda ini yang saat ini berada di jenjang pendidikan sekolah dasar hingga perguruan tinggi sudah tidak menguasai lagi bahasa Bugis. Mereka pada umumnya menggunakan bahasa Indonesia sebagai sarana komunikasi di sekolah dan di masyarakat. Jika keadaan ini terus berlangsung, diperkirakan sekitar dua hingga tiga generasi ke depan, bahasa Bugis sudah tidak digunakan lagi oleh komunitas Bugis Pagatan.

\section{Penamaan Orang dan Kampung}

Orang Bugis Pagatan, terutama mereka yang berumur 30 tahun ke atas, masih banyak yang menggunakan nama Bugis. Sejumlah orang yang ditemui memiliki nama yang berciri khas Bugis, seperti Ambo Tuo dan Indo Tuo, Mappatokkong, Tenri, Baco, dan lain-lain. Penggunaan nama orang seperti ini juga dipandang sebagai upaya orang Bugis Pagatan mempertahankan identitas budayanya. Akan tetapi, kalangan muda Bugis Pagatan saat ini sudah tidak menggunakan nama yang bercirikan identitas Bugis lagi. Pada umumnya mereka menggunakan nama panggilan 
bercirikan Islam, seperti Muhammad Ilham, Ainun, Muhammad Yusuf, Anwar, dan lainlain, serta banyak pula menggunakan namanama populer atau yang mendapatkan pengaruh sinetron populer, seperti Rayhan, Dedi, Raisya, dan lain-lain.

Tidak hanya penamaan orang, upaya orang Bugis Pagatan mempertahankan identitas kebugisannya ditandai dengan penamaan kampung mereka. Sebagaimana telah disebutkan pada pembahasan terdahulu, terdapat beberapa kampung yang menggunakan nama Bugis, seperti Gusungnge (kampung), Pekkae (perempatan), dan bahkan terdapat nama desa Wiring Tasi (pinggir laut/pesisir pantai).

\section{Pakaian Tradisonal, Pelaksanaan Ritual dan Makanan Tradisioal}

Penggunaan pakain tradisional Bugis di kalangan orang Bugis Pagatan dapat dilihat pada saat pelaksanaan ritual atau upacara, seperti perkawinan dan mappanre tasiq. Pakaian adat yang berciri Bugis yang digunakan, diantaranya jas tutup dan songkok to Bone serta pakaian pengantin Bugis. Akan tetapi, pakaian adat tersebut telah mendapatkan pengaruh pakaian adat Banjar, terutama dalam penggunaan sarung.

Demikian pula dalam prosesi pelaksanaan ritual masih banyak diantaranya yang mengikuti tradisi yang berlangsung di kalangan orang Bugis di Sulawesi Selatan. Bahkan dalam pelaksanaan prosesi perkawinan masih ada keluarga tertentu yang mejalankan tahapan-tahapan perkawinan, yang dimulai dari tahap mammanuq-manuq (mencari calon anak menantu), mattangke (menjalin hubungan), madduta (mengirim utusan untuk melamar), mappenre dui (menyampaikan uang belanja), hingga tahap menre kawing (rangkaian perkawinan) (faisalbatennie.blogspot.co.id/2 010/07/sejarah-kerajaan-orang-bugis-di-banua. html.)

Ritual yang paling populer di Kabupaten Kusan Hilir adalah upacara mappanre tasiq yang merupakan agenda tahunan orang Bugis Pagatan. Mappanre tasiq merupakan upacara mengungkapkan rasa syukur kalangan nelayan Bugis Pagatan. Upacara ini dilaksanakan setiap bulan April. Pelaksanaannya berlangsung di tengah laut, yang dipimpin oleh seorang sanro, digiring dan diikuti oleh kapal-kapal para nelayan. Rangkaian upacara ini berupa pagelaran seni budaya baik atraksi seni budaya Bugis Pagatan maupun etnis lain yang ada Kabupaten Kusan Hilir, serta dirangkaian acara perjamuan makan dan minum. Tidak diketahui kapan upacara ini dimulai, tetapi orang mencatat bahwa pada awal abad ke-20 pelaksanaan upacara ini sudah ramai diikuti oleh pengunjung dari berbagai daerah. Dalam sepuluh tahun terakhir, pelaksanaan upacara ini semakin ramai dan bahkan menjadi agenda tahunan Pemerintah Kabupaten Kusan Hilir.

Prosesi upacara mappanre tasiq dimulai dari tahapan penetapan waktu oleh sesepuh nelayan atau pemangku adat, juragan (ponggawa) dan dukun (sanro) dan imam mesjid (Pua Imang). Selanjutnya penyiapan biaya oleh ponggawa, juru mudi, dan juru batu. Kalangan perempuan menyiapkan perlengkapan ritual. Hal yang disiapkan antara lain sepasan pengantin adat Bugis, dan sejumlah penari mappakaraja. Pihak yang memandu acara adalah penata adat.

Penata Adat sebagai pemandu acara. Pada saat pelaksanaan upacara dimulai, rombongan sanro mengambil tempat berangkat berangkat dari rumah Kepala Kampoeng menuju panggung adat. Mereka diarak dengan menggunakan perahu. Setelah tiba di panggung adat, sanro segera naik kepanggung adat untuk mengambil perlengakapan upacara. Selanjutnya sanro turun ke laut dengan diiringi para sesepuh adat, punggawa, dan lain-lain. Upacara inti mappanre tasiq berlangsung di laut yang ditandai dengan pemotongan ayam hitam (manu Tolasi), kemudian darahnya ditaburkan di dalam air laut sekitar perahu sanro berlabuh. Setelah diadakan acara doa bersama menadai selesainya prosesi acara ritual mappanre tasiq (faisalbettanie. blogspot.co.id /2010/07/Bugis Pagatan-dan-budaya-mappanretasi-html).

Selain itu, identitas Bugis yang masih dipertahankan oleh orang Bugis Pagatan adalah makanan tradisional. Makanan tradisioal di pasar Pagatan masih dapat dijumpai jenis kuekue tradisional Bugis seperti tarajju (dari tepung beras pulut dan gula aren), onde-onde (sejenis klofon), dan lain-lain. Demikian pula sajian makanan di rumah-rumah orang Bugis, masakan yang wajib adalah nasu bale (ikan masak dengan asam kunyit).

Demikian orang Bugis Pagatan masih mempertahankan identitas budayanya baik di 
rumah maupun di ranah publik. Meskipun demikian, mereka menerima keberadaan etnis lain, dengan memasukan unsur budaya etnis lain ke dalam upacara atau ekspresi kebudayaannya. Hal ini merupakan salah satu strategi orang Bugis untuk eksis di tengahtengah masyarakat yang multikultur.

\section{KESIMPULAN}

Identitas Bugis Pagatan tidaklah bersifat esensialis dalam arti seseorang dapat dilihat semata-mata sebagai orang Bugis, namun pada diri seseorang tersebut melekat beragam identitas lainnya. orang Bugis dikenal sebagai pekerja keras dan sukses dalam membuka sektor ekonomi yang belum tereksploitasi sebelumnya dengan cara membuka lahan pertanian, mengembangkan ternak ikan dan mendirikan usaha kecil. Bidang yang terakhir itulah yang juga ditemukan pada masyarakat Bugis Pagatan.

Persentuhan antara tradisi Islam dengan warisan keyakinan-keyakinan Bugis kuno melahirkan sebuah praktik kebudayaan yang berbeda dengan kehidupan orang Bugis di Sulawesi atau di tempat lainnya. Beberapa kelompok masyarakat bisa menerima keberadaan keduanya dalam arti budaya Bugis dianggap dapat dipadukan dengan tradisi dan paham Islam. Jika ditelusuri kelompok yang menerima hal tersebut adalah mereka yang Islam sangat dipengaruhi oleh ajaran tasawuf yang tidak terlalu mementingkan syariat atau apa yang tampak dalam praktiknya. Sementara terdapat pula kelompok yang sangat keras menentang perpaduan agama dan budaya. Bagi kelompok seperti ini, ritual mapanretasi dianggap musyrik sebab dalam salah satu proses ritual tersebut, pemimpin upacara yang disebut juga sebagai Sanro mempersembahkan sesajen berupa ayam yang dilarung ke laut.

\section{Ucapan Terima Kasih}

Terima kasih diucapkan kepada seluruh pihak yang terlibat dalam penelitian ini, dan terima kasih kepada Kapata Arkeologi yang mempublikasikan hasil penelitian ini dalam bentuk artikel ilmiah.

\section{DAFTAR PUSTAKA}

Abdullah, Irwan. (2006). Konstruksi dan Reproduksi Kebudayaan. Yogyakarta. Pustaka Pelajar.

Appadurai, A. (1994). Global Ethnoscapes: Notes and Queries for transnational Anthropology. In Modernity at Large (pp. 48-65).

Bakti, A. F. (2010). Diaspora Bugis di Alam Melayu Nusantara. Makassar: Ininnawa.

Geertz, Clifford. (1992). Tafsir Kebudayaan. Yogyakarta: Kanisius.

Mansyur. (2011). Diaspora Suku Bugis dan terbentuknya Identitas To-Ugi' di Wilayah Tanah Bumbu, Residensi Borneo Bagian Selatan dan Timur, Tahun 1900-1942. Citra Lekha, 6(2), 67-82.

Kaplan, A., \& Manners, R A. (2002). Teori Budaya. Simatupang, L. (Ed.). Yogyakarta: Pustaka Pelajar.

Kramsch, C. (1998). Language and Culture. Oxford: Oxford University Press.

Labov, William. (1972). The Linguistics Consequences of Being a Lame. Language in The Inner City. Pennsylvania: Pennsylvania University Press.

Thomas, Linda dkk. (2005). Language society and power. London: Routledge.

Otavio, Velho. (2000). Globalization: ObjectPerspective-Horizon. Journal of Latin American Anthropology, 4(2), 320-339.

Parekh, B. (2000). Rethinking Multiculturalism. London: Palgrave.

Renan, E. (1997). Qu'est-ce Qu'une Nation. Paris: Mille et une nuits.

Ricoeur, P. (1981). Hermeneutics and the Human sciences. Thompson, J. B. (Ed.). Cambridge: Cambridge University Press.

Tsing, Anna. (2000). The Global Situations. Journal Cultural Anthropology, 15(3), 327-360. 